\title{
Influence of Pseudonymous Identity Usage on Instagram on Self-disclosure
}

\author{
http://dx.doi.org/10.25008/jkiski.v6i2.572
}

\author{
Nesya Pravitasari Suherman ${ }^{1 *}$, Dhita Widya Putri ${ }^{2}$, Yolanda Stellarosa ${ }^{3}$ \\ ${ }^{1,3}$ Communication Study in Postgraduate Programme, Institut Komunikasi dan Bisnis LSPR \\ Sudirman Park, Jl. KH. Mas Mansyur Kav. No. 35 Jakarta 10220 - Indonesia \\ ${ }^{2}$ LLDIKTI Wilayah III Jakarta \\ Jl. SMA Negeri 14 No. 4, Jakarta 13630 - Indonesia \\ *Corresponding author: 19220140368@1spr.edu; nesyasuherman@gmail.com
}

Submitted: June 12, 2021, Revised: September 15, 2021, Accepted: October 10, 2021

Accredited by Kemristekdikti No. 28/E/KPT/2019

\begin{abstract}
One of many social media phenomena, especially on Instagram, is the rising number of accounts with pseudonymous identity, commonly known as Fake Instagram (Finstagram). A private account appears with a fake username and photo display and small number of followers, with the purpose of being unidentified. The phenomenon starts from the social media standards Instagram trends to social judgements, resulting in users feeling uncomfortable when sharing aside from the implicit standards and trends which are currently happening. From that perspective, this research aims to see whether an influence is present in pseudonymous identity usage on Instagram on self-disclosure. Data of this research is gathered from 100 respondents through questionnaire using a purposive sampling technique. The result of questionnaire is later researched using a quantitative research method. With the use of simple regression analysis, it is known that pseudonymous identity usage on Instagram (variable X) and self-disclosure (variable Y) have a strong correlations and a significant influence on one another. Based on self-disclosure theory, the result shows that pseudonymous identity usage on Instagram (also known as Finstagram) contributed $43,6 \%$ to self-disclosure, whereas the remaining $56,4 \%$ is contributed by other factors than pseudonymous identity usage on Instagram.
\end{abstract}

Keywords: pseudonymous identity; self-dosclosure; instagram; social media; mass communications

\section{Introduction}

As a social creature, humans depend on each other in life to survive. Fundamentally, people interact as a basic form of communicating with one another, purposing to deliver a message. Information, speech, stories, confidence, proposal, disappointment and anger expression, are instances of how people interact.

There are at least two general settings in which people communicate by, formal and informal. In a formal setting, formal languages are used, handshakes and formal gesture are practiced, and the subjects discussed are even work-related in accordance with the company's interest. On the contrary, warmth and ease are usually displayed in an informal setting. People hug, share laughter and personal stories, displaying a relaxed and comfortable body language.

The aspect of difference on both settings lies in the presence of familiarity, trust and comfort. It is formed by self-disclosing practiced by communicator and its communicant. Communication process is usually weak in organizations because there is no self-disclosure among individuals (Harapan \& Ahmad, 2014). While with family or friends, 
self-disclosing is done naturally.

According to Pearson, Nelson, Titsworth and Hosek, (2013), self-disclosure is a selfprocess of opening up regarding personal, sensitive or confidential matter, most likely not known by others. According to Jourard (as cited in Pearson, Nelson, Titsworth and Hosek, 2013), self-disclosure makes one 'transparent' to others. In other words, one can be distinguished and identified uniquely by selfdisclosing. Usually, giving out significant information is what makes disclosure happen, not general information known by public (West \& Turner, 2010).

In the past, interactions were commonly done directly - face to face, whereas today they are done virtually online (Sukendar, 2017). With the rapid development of technology, online interactions on social media become more popular and commonly utilized by society. This is also in line with the research conducted by Handoko and Stellarosa (2020) which states that the needs of social media accounts are raising, not only for young people but also for various groups such as entrepreneurs, community, activists, even country leaders.

In 2019, according to Kemp (2019), the number of social media users in Indonesia increased by $15 \%$ as compared to the previous year, 2018. Within just a year, the increase is equivalent to 20 million people, taking the total number of active social media users on Instagram to 150 million. This means that $48 \%$ of the Indonesia population - almost half of the entire population - are active social media users.

Out of many popular social media platforms in Indonesia, the average result of four credible survey studies shows that 95.5 million $(80 \%)$ of Indonesian internet users use Instagram (Kemp, 2019). Kemp (2019) also stated that it is the $4^{\text {th }}$ most popular social media platform after YouTube, WhatsApp and Facebook respectively. The vast majority of Instagram users are young, educated and established people (Nuryadin, Dewi, Mustika \& Ningrum, 2020). Interactions shift to online platform, and so does self-disclosure. People self-disclose through their shares online. Social media and the internet is the new platform to practice self-disclosure.

Instagram becomes a social media platform that is very influential to people's social lives (Amelia \& Hidayatullah, 2020). To date, Instagram is even used as a primary source of information (Gelgel, Apriani, Ginting, 2020).
On Instagram, millions of people share information, stories, thoughts and experiences on a daily basis. Self-disclosure is poured through lengthy captions, meaningful and memorable photos, confidence in videos and many more. Instagram users are greatly facilitated to be able to communicate with other users, just like creating a world with user's own terms and conditions (Yuliarti, Siagian \& Wardaningtyas, 2020).

However, self-disclosing in a borderless digital world also has its consequences. Many feel like their social presence at a time makes them an object freely accessible by the world. Anyone can say anything at any time. With no rigid control and boundaries, anyone is able to have access to one's shares and take actions upon one online; like, dislike, comment, judge and follow on social media.

Another discomfort is never-ending trends on social media. One of the trends on Instagram is three-same-themed photos arranged in one line displayed on one's Instagram page (Fauzi, 2017). Every line displays different photo theme. The idea of this concept is to have a neat and aesthetic Instagram page, so that it pleases whoever visits the page. However, the implicit trend that serves the image of Instagram account without concept is less attractive. A user who wants to post freely without following trend is pressured.

The neatness and arrangements displayed on themed Instagram accounts creates an unwritten standard subject to be followed when uploading a photo or video on Instagram (Finstagram, Fake Account Trends Popular Among Indonesian Teenagers, 2018). To achieve a consistent themed photo display, one has to go through precise editing, color correcting, brightness adjusting and cropping.

From the discomfort and limitation to express one-self freely on Instagram, (Finstagram) phenomenon occurred. According to Refinery29 (as cited in Finstagram, Fake Account Trends Popular Among Indonesian Teenagers, 2018), Finstagram is the abbreviation of Fake Instagram. The Finstagram phenomenon or trend crowded worldwide in 2015, after previously trending on Twitter (Hutomo, 2018). In Indonesia, Finstagram is commonly known as Second Account.

A Finstagram account does not display any real information related to its user. According to Fauzi (2017), one creates a Finstagram account with the purpose of being unidentified and found by search engines. The choice of 
username and profile photo is fake, with a status or bio referring to secrecy and confidentiality, the Instagram account set in private with followers of only the closest friends. Content wise, a Finstagram account is filled with random photos and selfies, daily rants, confidences about love and life, gossips and humors (Fauzi, 2017).

From its content types, Finstagram users disclose more through what they share, because no one is there to judge. It is a safe place to upload random and intimate photos and videos, without having to worry about what other people think (Finstagram, Fake Account Trends Popular Among Indonesian Teenagers, 2018). On Finstagram, one can freely express through shares without worrying about certain standards or trends, and even themed photos are created to please profile visitors (Fauzi, 2017).

That is the tremendous yet terrible effect technology that has upon us as users. Borderless access to information instead makes internet scream for boundaries, protecting themselves from being a digital object accessible by anyone, anywhere, any time.

This research is conducted with the aim of determining influence of pseudonymous identity usage on Instagram on self-disclosure, and the greatness pseudonymous identity usage that presents on self-disclosure quantitatively.

\section{Theoretical Framework}

Research conducted by Mailoor, Senduk and Londa (2017) aims to perceive the influence of Snapchat users to self-disclosure by Sam Ratulangi University students concentrating in Communications. This first research is based on self-disclosure theory, which is based on human interactions, and new media theory as a supporting theory.

The researcher hypothesized that Sam Ratulangi University Snapchat users have an influence on self-disclosure. Using a quantitative method, the result of this research shows that there is a correlation between Sam Ratulangi University Snapchat users and selfdisclosure. Furthermore, Sam Ratulangi Snapchat users have an influence on selfdisclosure.

The second research is conducted by Desmarwita (2013). Through her research, the researcher aims to answer several problematic statements found. First, to explain the causes of Social Science Faculty University Negeri Padang (FIS UNP) students majoring in Sociology to use pseudonymous identity on Facebook. Second, to describe the form of pseudonymous identity used by the FIS UNP students majoring in Sociology. To analyze the actor's behavior, the researcher uses rational choice theory, and gratification theory to analyze the medium of social media.

Using a qualitative method, the researcher found that the causes of FIS UNP students to use pseudonymous identity on Facebook are to update dirty status, chat, conduct research, achieve self-comfort, and follow trends as well as for personal nicknames. FIS UNP students display pseudonymous identity on Facebook through name, photo, address, job or education and relationship.

The third research is conducted by Dewar, Islam, Resor and Salehi (2019). with the aim of perceiving the phenomenon of Finstagram to display self-authenticity. Based on dramaturgy theory, the researcher focuses on the thought of self-presentation. The research focuses on analyzing the Finstagram phenomenon, without perceiving the correlation or influence on a dependent variable.

The research was conducted using the combination of qualitative and quantitative methods. It was started by disseminating questionnaires on Instagram to 81 respondents with more than one Instagram account, defined as Finstagram. Afterwards, three respondents were taken for a 45-minute interview for an indepth point of view qualitatively.

The result shows that Finstagram users limit the number of audience (followers), as it is a platform for users to share contents they might not feel comfortable to share on their real Instagram account. Contents shared are humor, self-authenticities, and pictures without filters.

Self-disclosure Theory by Joseph Luft is based on human interaction, provided in Johari Windows (Syahputra, 2016). Johari Windows is a four-paneled window that provides different information about a person in each panel, including open area, blind area, hidden area and unknown area (Pearson, Nelson, Titsworth and Hosek, 2013). All four quadrants in each panel represents different ways that one accesses information seen and observed, directly from within or from others (Liliweri, 2015).

The quadrants in each panel of Johari Window is further explained as follows (Pearson, Nelson, Titsworth and Hosek, 2013):

Open area, consists of information known by public. In this panel, information is general and not confidential. Thus, one does not feel uncomfortable and bothered when information in this panel is widespread. Birthday, hobbies, favorite food and drinks are instances of 
information in this panel.

Blind area, is called so because it is seen and known by others, but not by one-self. Information that falls under this quadrant is behavior and personalities seen by others, or unconscious habits.

Hidden area, is the third quadrant hidden by one-self from others. One does not open up information in this quadrant to others.

Unknown area, consists of information that is unknown by both others and one-self. Information in this quadrant is only known upon certain circumstances, otherwise, the information remains unknown.

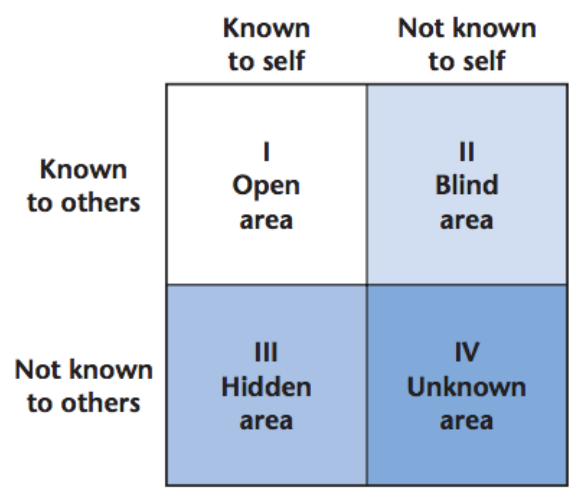

Figure 1. Johari Windows

Source: Pearson, Nelson, Titsworth and Hosek (2013

\section{Material and Methodology}

This research is conducted using a quantitative research method. Quantitative method falls into post-positivism paradigm. The main key of a post-positivism paradigm is testing. Researches with this paradigm aim to describe an observed and measured phenomenon. Unmeasurable aspects such as feelings, thoughts and emotions are unconsidered (Sekaran \& Bougie, 2016).

According to Cooper and Schindler (2014), a quantitative research requires precise calculation and measurement of an object by describing, testing or predicting a result through hypothesis. In other words, quantitative research is closely related to numbers, calculations and measurements.

A quantitative method is used in this research, because it is able to resolve research problems. Aiming to test theory, a quantitative research lays out number, without in-depth analysis of other unmeasurable factors.

Research population in this research are millennial students or workers who use Instagram, specifically Finstagram. However, from the above-mentioned criteria, the number of population is unidentified. Therefore, this research has an infinite population.

This research is represented by 100 samples as respondents. Samples should be a millennial (men and women) who has a Finstagram account. According to Ahyad, Widjajanto and Consulting (2016), age groups that are considered millennials are the last two generations, namely generation $\mathrm{Y}$ and $\mathrm{Z}$. This means those born between 1980-1994 and 1995-2010. Specifically, millennials aged 1728 years, in accordance with age range of Instagram users.

Questionnaire is developed with reference to variable operations, both independent and dependent. Pseudonymous identity usage (variable X) consists of seven indicators and 14 indicators from Desmarwita (2013) and Dewar, Islam, Resor and Salehi (2019). Meanwhile, self-disclosure (variable $\mathrm{Y}$ ) consists of 2 dimensions and six indicators from Griffin (2012).

Table 1. Variable Operations of Pseudonymous Identity Usage (Variable X

\begin{tabular}{|l|l|l|}
\hline Variable & Dimension & Indicator \\
& By name & Username uses random elements \\
& Username aims to hide identity \\
& Photos used are random and fake \\
& By photo & Photo used aims to hide identity \\
& Bddress used are random and fake \\
\hline
\end{tabular}




\begin{tabular}{|l|l|l|}
\hline & & $\begin{array}{l}\text { Domicile used are random and fake } \\
\text { Educational background/occupation } \\
\text { Pseudymous identity } \\
\text { usage }\end{array}$ \\
& Bventioned are fake \\
& Present humor, authenticity and \\
& confidence & $\begin{array}{l}\text { Limits number of followers } \\
\text { Shares humor } \\
\text { Shares authenticity } \\
\text { Shares confidence } \\
\text { Feels free from judgement } \\
\text { Does not filter/edit contents upon } \\
\text { posting }\end{array}$ \\
& Reduce pressure of jugdements & Feels free to share personal contents \\
\hline
\end{tabular}

Source: Researcher's Organic Data, 2020

Table 2. Variable Operations of Pseudonymous Identity Usage (Variable X)

\begin{tabular}{|c|c|c|}
\hline Variable & Dimension & Indicator \\
\hline \multirow{6}{*}{ Self-disclosure } & \multirow{3}{*}{ Depth } & $\begin{array}{l}\text { Condifential and personal level of } \\
\text { information escalates through time }\end{array}$ \\
\hline & & Pay attention to shares of followers \\
\hline & & Have trust towards followers \\
\hline & \multirow{3}{*}{ Breadth } & $\begin{array}{l}\text { Privates Finstagram accounts to followers } \\
\text { only }\end{array}$ \\
\hline & & $\begin{array}{l}\text { Considers people to allow access to } \\
\text { account }\end{array}$ \\
\hline & & Filters followers with close friend feature \\
\hline
\end{tabular}

Source: Researcher's Organic Data, 2020

\section{Result and Discussion}

Of 100 respondents, $84 \%$ are women and $16 \%$ are men. In terms of age, $81 \%$ of respondents are between 21-24 years old, $12 \%$ are between 1-20 years old and 7\% are between 25-28 years old. The researcher ensures that every respondent owns a Finstagram account as criteria, since Finstagram is the prime subject of this research.

Using Likert scale, questionnaire is disseminated to 100 respondents that meet sample requirements as mentioned before. The scale consists of five intervals as follows; 1 strongly disagree, 2 - disagree, 3 - neutral, 4 agree, and 5 - strongly agree.

\section{Descriptive Analysis}

The descriptive analysis of pseudonymous identity usage shown on Table 1 perceives the highest answer average (mean) resulted in statement 8 , at 4.21 out of 5 . On the contrary, the lowest average (mean) resulted in statement 7 , at 3.13 out of 5 .

Table 3. Descriptive Analysis of Pseudonymous Identity Usage (Variable X)

\begin{tabular}{|l|c|}
\hline Statement & $\begin{array}{l}\text { Mean Per } \\
\text { Item }\end{array}$ \\
\cline { 1 - 2 } Finstagram username is random elements irrelevant to identity & 3.71 \\
\hline Finstagram username aims to hide identity & 4.01 \\
\hline Finstagram photo is random and irrelevant to identity & 3.33 \\
\hline Finstagram photo aims to hide identity & 3.61 \\
\hline Finstagram address is random and irrelevant to current domicile & 3.60 \\
\hline Finstagram location is random and irrelevant to current domicile & 2.81 \\
\hline $\begin{array}{l}\text { Educational background/occupation is random and irrelevant to } \\
\text { identity }\end{array}$ & 3.13 \\
\hline Limits number of followers & 4.21 \\
\hline Shares humor on Finstagram & 3.84 \\
\hline Shares authenticity on Finstagram & 4.15 \\
\hline Shares confidence on Finstagram & 4.03 \\
\hline Feels free of judgement when posting on Finstagram & 4.09 \\
\hline
\end{tabular}




\begin{tabular}{|l|l|l|}
\hline Does not filter/edit content upon posting & 3.79 & \\
\cline { 1 - 2 } Shares personal and upclose contents & 3.42 & \\
\cline { 1 - 2 }
\end{tabular}

Source: Researcher's Organic Data, 2020

Meanwhile, descriptive analysis of selfdisclosure as dependent variable (variable Y) shown on Table 2 perceives the highest answer average (mean) resulted in statement 5 , at 4.59 out of 5 .
On the contrary, the lowest average (mean) resulted in statement 6 , at 3.12 out of 5 .

Table 4. Descriptive Analysis of Self-disclosure (Variable Y)

\begin{tabular}{|l|c|c|}
\hline Statement & $\begin{array}{l}\text { Mean Per } \\
\text { Item }\end{array}$ & Mean Per Variable \\
\hline $\begin{array}{l}\text { Confidential level of information being shared escalates } \\
\text { through time }\end{array}$ & 3.83 & 3.69 \\
\cline { 1 - 2 } $\begin{array}{l}\text { Pays attention to contents shared by followers to know about } \\
\text { them }\end{array}$ & 3.75 \\
\hline Gain and maintain trust to followers on Finstagram & 4.44 \\
\cline { 1 - 2 } $\begin{array}{l}\text { Finstagram account is on private and restricted to followers } \\
\text { only }\end{array}$ & 4.59 \\
\hline Considers people to allow acces to Finstagram account & 3.12 \\
\hline Filters Finstagram followers using close friend feature & \multirow{2}{*}{3.90} \\
\hline
\end{tabular}

Source: Researcher's Organic Data, 2020

\section{Correlation}

This research carries a linear correlation, consisting of one independent variable (variable $\mathrm{X}$ ) and one dependent variable (variable $\mathrm{Y}$ ). According to Pearson's Product Moment Correlation ruling, the more the correlation's coefficient is closer to 1 , the stronger the correlation is among present variables (Sarwono, 2015).
In this research, both variables present a correlation coefficient of 0.660 as shown on Table 5. As the number is positive and not otherwise, it shows that the correlations between pseudonymous identity usage and selfdisclosure is linear. This means that the more one uses pseudonymous identity on Instagram, the more one self-discloses. With the same ruling, the less one uses pseudonymous identity usage on Instagram, the less one self-discloses.

Table 5. Pearson's Product Moment Correlation

\begin{tabular}{|l|l|r|r|}
\multicolumn{2}{c|}{ Table 5. Pearson's Product Moment Correlation } \\
\hline \multirow{4}{*}{$\begin{array}{l}\text { Pseudonymous } \\
\text { Identity }\end{array}$} & Self-disclosure \\
\hline \multirow{2}{*}{$\begin{array}{l}\text { Pseudonymous } \\
\text { Identity }\end{array}$} & Pearson Correlation & 1 & $.660^{* *}$ \\
\cline { 2 - 4 } & Sig. (2-tailed) & 100 & .000 \\
\cline { 2 - 4 } Self-disclosure & $\mathrm{N}$ & $.660^{* *}$ & 100 \\
\hline & Pearson Correlation & .000 & 100 \\
\cline { 2 - 4 } & Sig. (2-tailed) & 100 & 1 \\
\cline { 2 - 4 } & $\mathrm{N}$ & & \\
\hline
\end{tabular}

Source: Researcher's Organic Data, 2020

\section{Coefficient of Determination}

The coefficient determination table shown in Table 6 states the degree of contribution variable $\mathrm{X}$ has upon $\mathrm{Y}$, implemented in $\mathrm{R}^{2}$. As shown on Table 6 , pseudonymous identity usage contributes $43.6 \%$ to self-disclosure, while the rest of $56.4 \%$ of self-disclosure is contributed by other factors aside from pseudonymous identity usage.

Table 6. Coefficient of Determination

\begin{tabular}{|r|r|r|r|r|}
\hline Model & R & R Square & $\begin{array}{c}\text { Adjusted } \\
\text { R Square }\end{array}$ & $\begin{array}{c}\text { N of } \\
\text { Items }\end{array}$ \\
\hline 1 & $.660^{\mathrm{a}}$ & .436 & .430 & 3.524 \\
\hline
\end{tabular}

Source: Researcher's Organic Data, 2020 


\section{Linear Regression}

Referring to the linear regression shown on

Table 7, regression coefficient of pseudonymous identity is 0.279 . This means that every one increasing unit of pseudonymous identity usage (variable $\mathrm{X}$ ) equals to 0.279 times the increase of self-disclosure (variable Y).

The ruling also applies to every decreasing unit of both variables. Should pseudonymous identity usage not influence self-disclosure, influence occurs from other influencing factors aside from pseudonymous identity usage.

Table 7. Linear Regression

\begin{tabular}{|l|l|c|c|c|c|c|}
\hline & & $\begin{array}{c}\text { Unstandardized } \\
\text { Coefficients }\end{array}$ & $\begin{array}{c}\text { Standardized } \\
\text { Coefficients }\end{array}$ & & & \\
\hline Model & & $\mathrm{B}$ & Std. Error & Beta & $\mathrm{t}$ & Sig. \\
\hline 1 & Constant & 8.964 & 1.699 & & 5.277 & .000 \\
\hline & $\begin{array}{l}\text { Self- } \\
\text { disclosure }\end{array}$ & .279 & .032 & .660 & 8.699 & .000 \\
\hline
\end{tabular}

Source: Researcher's Organic Data, 2020

\section{ANOVA}

Table 8 perceives whether pseudonymous identity usage presents influence on selfdisclosure. $F$ value is one determination. With simple regression -one independent and one dependent variable in this research, $\mathrm{F}_{\text {table }}$ value is 3.95 .

To conclude that this research has an influence, $F_{\text {tally }}$ should be greater than 3.95. On the ANOVA table below, it is seen that $F$ value is 75.581 . This means that value is way greater than 3.95 and thus, an influence is present.

Another measurement, it is shown that significance value is .000 rejecting hypothesis ${ }^{0}$ $\left(\mathrm{H}_{0}\right)$ and at the same time accepting hypothesis ${ }^{1}$ $\left(\mathrm{H}_{1}\right)$, based on the ruling that significance value $<.005$ means that influence is significant. Thus, pseudonymous identity usage on Instagram presents a significant influence on selfdisclosure

Table 8. ANOVA

\begin{tabular}{|c|l|c|c|c|c|c|}
\hline Model & & $\begin{array}{c}\text { Sum of } \\
\text { Squares }\end{array}$ & df & $\begin{array}{c}\text { Mean } \\
\text { Square }\end{array}$ & F & Sig. \\
\hline 1 & Regression & 939.628 & 1 & 939.628 & 75.581 & $.000^{\mathrm{b}}$ \\
\hline & Residual & 1216.732 & 98 & 12.416 & & \\
\hline & Total & 2156.360 & 99 & & & \\
\hline
\end{tabular}

Source: Researcher's Organic Data, 2020

According to the analysis explained, every research indicator puts up a contribution with various values. Both variables, pseudonymous identity usage and self-disclosure present two dimensions each.

Dimensions of pseudonymous identity usage are a form of pseudonymous identity usage and purpose of pseudonymous identity usage. The most influencing dimension on selfdisclosure is purpose of pseudonymous identity usage, with an average respondent answer of 3.93. Furthermore, the most influencing indicator of the dimension on self-disclosure is limiting the number of followers on Finstagram account, with respondent's average answer of 4.21.

Respondents restrict the number of followers to close friends and relatives only in order to avoid context collapse, a situation where mixed audience meet. The small number of followers are people desired by the Finstagram, who shares familiarity, comfort and intimacy.

On the other hand, the least influencing dimension influencing self-disclosure is a form of pseudonymous identity usage with an average answer of 3.46. Specifically, the most influencing indicator of the dimension is the use of pseudonymous domicile background of 2.81

Unlike Facebook who provides detailed profile features such as hobbies, occupation, address, sibling, etc., Instagram presents a bio box, letting users freely express themselves without subtitles. Thus, pseudonymous identity usage upon domicile background on Instagram does not influence as much as on usernames or photos.

Just like pseudonymous identity usage, self-disclosure also presents two dimensions, namely breadth and depth. Dimension highly 
influenced is breadth with an average of 4.05. It is mostly contributed by indicator of private Finstagram account restricted for closest people only of 4.59 .

Meanwhile, the least influenced dimension is depth, specifically in indicator of filtering Finstagram followers using Close Friend feature, with average answer of 3.12. As Finstagram is intended for an up-close and personal content shares and followers, it is redundant for Finstagram users to use Close Friend feature, for it serves more less the same purpose.

Application of self-disclosure theory in this research is seen from quadrant magnitude of each panel in Johari Windows. Pseudonymous identity usage magnifies hidden area of the window, making it the largest area over the other three. On Finstagram, instances of information that fall in hidden area are random selfies and videos, love and life confidences, humor to natural photos without edits or filters.

\section{Conclusion}

From discussion explained, several key findings in perceiving the influence of pseudonymous identity usage on Instagram on self-disclosure result in a particularly various landscapes. It is based on the research question and purpose.

It is found in this research that pseudonymous identity usage on Instagram presents a significant influence on selfdisclosure. The more one leverages pseudonymous identity usage on Instagram, the more self-disclose one is to its audience.

This research also found several other findings to be insightful about the subject of this research. Firstly, Finstagram is mainly favored by women. Women dominate the usage percentage by $84 \%$ as compared to men. Secondly, Finstagram users limit the number of followers, strictly to people who shares intimate friendship in which they trust, and connection and respect for privacy is mutually performed. Thirdly, Finstagram accounts are restricted to followers only upon private mode, enabling a request upon profile visits. This means, only those approved by the owner of the account is able to have access to the profile and interact.

Otherwise, the general public is not able to access contents being shared. Last but not least, Finstagram users only self-disclose to followers and never to greater number of audience beyond that.
The rapidly growing technology allows researchers to revolve topics of communication, specifically the use of internet and social media. Referring to research analysis and result, pseudonymous identity usage is not the only factor influencing self-disclosure on social media. Further researches can be conducted to determine those factors, whether on Instagram or other social media platforms.

\section{References}

Ahyad, A., Widjajanto, D., \& Consulting, KMPlus. (2016). Smart Millennials, Jakarta: PT Gramedia Pustaka Utama.

Amelia, R., \& Hidayatullah, S. (2020). The Effect of Instagram Engagement to Purchase Intention and Consumers' Luxury Value Perception as a Mediator in The Skylounge Restaurant. International Journal of Innovative Science and Research Technology. 5(4), 958-966.

Cooper, D. R., \& Schindler, P. S. (2014). Business Research Methods. New York: McGraw-Hill Education.

Desmarwita. (2013). Penggunaan "Identitas Semu" oleh Mahasiswa Jurusan Sosiologi FIS UNP di Jejaring Sosial Facebook. Jurnal Sosiologi. 1 (1), 9-16.

Dewar, S., Islam, S., Resor, E., and Salehi, N. (2019). Finsta: Creating 'Fake' Spaces for Authentic Performance. CHI Conference on Human Factors in Computing Systems. https://doi.org/10.1145/3290607.3313033

Gelgel, A., N., Apriani, K., \& Ginting, R. (2020). Communication Strategies in the 2020 Local Election Stages Socialization During the Covid-19 Pandemic. Jurnal Komunikasi Ikatan Sarjana Komunikasi Indonesia, 5(2), 205-216. doi:https://doi.org/10.25008/jkiski.v5i2.45 9.

Handoko. M., \& Stellarosa, Y. (2020). The Influence of President Joko Widodo's Instagram Content on Beginner Voters Participation in the 2019 General Election. MediaTor. 13(1), 24-38.

Harapan, E, \& Ahmad, S. (2014). Interpersonal Communication: Human Behavior in Educational Organization. Depok: PT Rajagrafindo Persada.

Kumparan. Finstagram, Tren Akun Palsu yang Populer di Kalangan Remaja Indonesia. (2018). Retrieved from: https://kumparan.com/millennial/Finstagr 
am-tren-akun-palsu-yang-populer-dikalangan-remaja-indonesia.

Liliweri, A. (2015). Interpersonal Communication. Jakarta: Prenadamedia Group.

Mailoor, A., Senduk, J. J., dan Londa, J. W. (2017). Pengaruh Penggunaan Media Sosial Snapchat Terhadap Pengungkapan Diri Mahasiswa Jurusan Ilmu Komunikasi Fakultas Ilmu Sosial dan Ilmu Politik Universitas Sam Ratulangi. E-Journal Acta Diurna. 4(1).

Nuryadin, M. E., Dewi, S. H., Mustika, A., \& Ningrum, L. (2020). Are Urban Teens Interested in Staying at a Homestay Through Instagram?. International Journal of Innovative Science and Research Technology. 5(12), 1044-1048.

Pearson, J. C., Nelson, P. E., Titsworth, S., \& Hosek, A. M. (2013). Human Communications. New York: McGrawHill Education.

Sarwono, J. (2015). Popular Formulas in SPSS 22 for Thesis Research. Yogyakarta: Penerbit ANDI.

Sekaran, U., \& Bougie, R. (2016). Research Methods for Business: A Skill-Building Approach. Chichester: John Wiley \& Sons Ltd.

Sukendar, M. U. (2017). Psychology Communications: Theory and Practice. Yogyakarta: Deepublish.

Syahputra, I. (2016). Communication Science: Perspective Tradition and Theory. Yogyakarta: Calpulis.

Tirto.id. Finstagram, Tempat Membuka Topeng Kepalsuan. (2017). Retrieved from: https://tirto.id/finstagram-tempatmembuka-topeng-kepalsuan-cmPj.

VICE. Finstagram Makin Populer di Indonesia, di Sanalah Terdapat Keaslian Dunia Maya. (2018). Retrieved from: https://www.vice.com/id_id/article/gywm e7/Finstagram-makin-populer-diindonesia-di-sanalah-terdapat-keasliandunia-maya

We Are Social. Digital 2019: Indonesia. (2019). Retrieved from: https://datareportal.com/reports/digital2019-indonesia.
West, R., \& Turner, L. H. (2010). Introducing Communication Theory: Analysis and Application. New York: McGraw-Hill Companies, Inc.

Yuliarti, M., Siagian, M., \& Wardaningtyas, A. (2020). Network Society and Social Movement: Message Reception among Instagram Users. Jurnal Komunikasi Ikatan Sarjana Komunikasi Indonesia, $5(2)$, 179-188. doi:https://doi.org/10.25008/jkiski.v5i2.38 2. 